\title{
I. Dünya Savaşı ve Sonrasında Kumarın Yaygınlaşması ve Osmanlı Devleti'nin Aldığı Tedbirler
}

\author{
Doç. Dr. Feyza Kurnaz Şahin \\ Afyon Kocatepe Üniversitesi \\ Atatürk İlkeleri ve İnkılâp Tarihi Bölüm Başkanlığı \\ fsahin@aku.edu.tr
}

Öz

Çalışmanın amacı I. Dünya Savaşı ve sonrasında sosyal çözülmenin bir göstergesi olarak kumarın yaygınlaşması ve devletin buna yönelik aldığı tedbirleri irdelemek olarak tanımlanır. I. Dünya Savaşı sırasında yaşanan ekonomik ve sosyal sıkıntılar nedeniyle artan yoksulluk, toplumu sefalete sürükledi. Olağan zamanlarda yapılması sakıncalı olan davranışlar aleni hale geldi. Bu dönemde Osmanlı toplumunda kumar, alkol, sefahat ve fuhuş gibi alışkanlıklar yaygınlaştı. I. Dünya Savaşı ve Mütareke döneminde kumarın artışı Osmanlı hükümetlerinin dikkatinden kaçmadı. Osmanlı hükümeti, kumarı önlemek için hukukî ve inzibatî tedbirler aldı. Bu kapsamda kahvehanelere ve diğer kumar oynanan mahallere polis baskınları düzenlendi. Diğer taraftan özellikle memurlar arasında yaygın hale gelen kumarı önlemek için bir nizamname çıartıldı. Ancak bu tedbirlere rağmen kumar tamamen önlenemedi. Zira kumarı doğuran sosyal ve ekonomik şartlar iyileştirilemediği için bu sorun Cumhuriyet döneminde de tartışılmaya devam etti. Çalışmanın temel kaynaklarını Cumhurbaşkanlığı Devlet Arşivleri Başbakanlığı Osmanlı Arşivinde yer alan belgeler ile dönemin süreli yayınları oluşturmaktadır.

Anahtar Kelimeler: I. Dünya Savaşı, kumar, fuhuş, mütareke, kahvehane.

\section{The Proliferation of Gambling and the Precautions Taken by the Ottoman State During and After the World War I}

\begin{abstract}
The purpose of the study is to investigate the proliferation of gambling as an indicator of the social disintegration and the precautions taken by the government against this during and after the World War I. Poverty that increased due to the economic and social problems encountered during the World War I led the community to live in misery. Behaviours that were normally seen as undesirable became overt. In this period, habits such as gambling, alcohol, debauchery, and prostitution became widespread in the Ottoman society. The increase in gambling during the World War I and Armistice Period did not escape from the attention of the Ottoman governments. The Ottoman government took legal and disciplinary precautions in order to prevent gambling. In this regard, police raids were carried out to coffeehouses and other places where gamble was played. Moreover, a regulation was made in order to prevent gambling which was common especially among civil servants. However, gambling could not be prohibited completely despite these precautions. This problem
\end{abstract}


continued to be discussed during the Republic Period due to the fact that the social and economic conditions causing gambling could not be improved. The main sources of the study are the documents of the Ottoman Archives of the Presidency and the periodicals of that period.

Keywords: World War I, gambling, prostitution, armistice period, coffeehouse. 


\section{GİRIŞ}

Kumar hemen bütün toplumlarda farklı adlar altında görülen ve kökleri çok eskilere dayanan bir şans oyunudur. Kumar, sebep olduğu çeşitli olumsuzluklar nedeniyle, dinen ve hukuken yasaklanmış ve kınanmıştır (Bardakoğlu, 2002, s. 364; Yolal, 2018, s. 6-19). Osmanlı Devleti de İslam Hukuku çerçevesinde hareket etmiş, kanunnamelerde ve kadılara gönderilen hükümlerde kumarın yasak olduğu mütemadiyen tekrarlanmış, kumar oynayanlar çeşitli cezalara çarptıılmıştır (BOA, A.DVNS.MHM.d, 35/225, Temmuz/Ağustos 1578).

Bu uyarılara rağmen kumar zaman içerisinde yaygınlık kazandı. Özellikle XIX. yüzyıl, Osmanlı coğrafyasında kumarın adeta salgın haline dönüştüğü bir dönemi ifade eder. Bu süreçte savaşlar, devletin içinde olduğu ekonomik ve siyasi sıkıntılar toplumsal hayatı derinden etkiledi. Hızlı dönüşüm, şehirlerdeki sosyal hayatın renklenmesine, bazı davranış ve zararlı alışkanlıkların görünür hale gelmesine sebep oldu (Toprak, 2017, s. 305-306).

Şer'i ve kanuni olarak yasak olmasına karşın kumar, sefahat, içki, eğlence ve fuhuş başta İstanbul olmak üzere imparatorluğun farklı şehirlerinde yayıldı. Osmanlı toplumunda kumarın ciddi boyutlara ulaştığı dönem XIX. yüzyılın ikinci yarısına rastlar. Bu dönem belgeleri incelendiğinde kumarla ilgili çok sayıda şikayetin varlığı göze çarpar (BOA, DH.ID., 891/2: 7-1, 8-1, 28 Ağustos 1910). Özellikle Kırım Savaşı ile birlikte İstanbul'a çok sayıda Rus savaş esirinin gelmesi ve bunların yaşadıkları yerlerde eğlence hayatının belirgin bir şekilde artması, umumhanelerin çoğalması fuhuş ve kumar gibi alışkanlıkların yayılmasına da neden oldu (Yakut ve Yetkin, 2011, s. 275).

Osmanlı hükümeti kumarın yaygınlaşmasını önlemek amacıyla çeşitli tedbirler alma yoluna gitti. Öncelikli olarak Ceza Kanununa kumarın suç olduğuna ilişkin esaslar kondu. Bu meyanda 14 Temmuz 1851 (Ahmed Lütfi, 1304, s. 127; Akgündüz, A. 1986, s. 821-831; Aydın, 1993, s. 481-482; Şentop, 2005, s. 653) ve 9 Ağustos 1858 tarihli Ceza Kanunlarına kumar ve diğer suçlarla ilgili hükümler yer aldı (Ceza Kanunname-i Hûmayunu, 1289, s. 591; Akgündüz, A. 1986, s. 873; Akgündüz, S. N. 2016, s. 11-12; Öner, 2013, s. 64). Yine 1869 Askeri Ceza Kanunnamesine (BOA, ŞD., 657/58: 8, 23 Ekim 1913) ve 1907 tarihli Polis Nizamnamesi'ne de kumarla ilgili esaslar eklendi (Polis Nizamnamesi, 1335, s. 637; Dikici, 2014, s. 95).

Sultan II. Abdülhamid döneminde de kumarla ilgili uyarı ve yasaklar sık sık tekrarlandı. Bu konuda Şûra-yı Devlet, kumarın her türlüsünün ve tombalanın yasak olduğuna ilişkin kararlar çıkardı (BOA, DH.MKT., 1778/69, 5 Kasım 1890). Ayrıca resmi makamlar arasında kumar yasağının ihlal edilmesi ve buna yönelik alınacak tedbirleri içeren yazışmalar da mevcut idi. Örneğin 9 Kasım 1904 tarihinde Sadrazam imzasıyla Dahiliye Nezareti'ne gönderilen yazıda, Osmanlı topraklarında kumar oyunlarının özel nizamnamelerle yasak olduğu, bu konuda zabıta tarafından gerekli tedbirlerin alınması gerektiği halde, Beyoğlu'nda bazı evlerde kumar oynamak için toplantılar düzenlendiğinin haber alındığı belirtildi. Bu durumun ortadan kaldırılması için kumarın şiddetli şekilde men edilmesi, kumar oynamak için yapılacak toplantıların engellenmesi, Zaptiye Nezareti'nin bununla ilgili gerekli tedbirleri alması istendi (BOA, DH.MKT., nr. 908/83, s. 1-1, 2-2, 9 Kasım 1904).

II. Meşrutiyet döneminde kumar daha da yaygın hale geldi. Kumar alışkanlığındaki bu artışlar aile ve toplum hayatını tehdit eder boyutlara ulaştı. Toplumun her kesiminden 
mahalle sakinlerinden, kadınlardan şikayetler artmaya başladı (BOA, DH.EUM.THR., 64/82: 1, 4, Nisan-Mayıs 1911). Bu meyanda vilayetlerden merkeze kumarın önlenmesi için tedbir alınmasıyla ilgili talepler dile getirildi. Bu nedenle kumarın denetim altına alınması için Ceza Kanunnamesinde kumarla ilgili hükümlerin yeniden düzenlenmesi ile ilgili çalışmalar yapıldı. Zira 1858 Ceza Kanunnamesinin kumarla ilgili hükümlerinde kumar oynayan kişiye verilecek ceza hususunda bir esasın bulunmamasına yönelik eleştiriler söz konusu idi. Ceza Kanunundaki bu açığın kumarın yaygınlaşmasına neden olduğu, vakti ve parası müsait olan kişilerin, ailelerinin eşyalarını satarak kumar oynamaya cüret edebildiği dile getirildi. Öte yandan kumarla ilgili hükümlerin eski olması nedeniyle zabıta tarafından yapılan muamelenin yetersiz kaldığı ya da tatbik edilemediği gerekçesiyle kumarın günden güne arttığ belirtildi (BOA, ŞD., 2364/1: 3, 7 Mart 1904; BEO., 2326/174390: 1-1, 2-1, 28 Nisan 1904; DH.MKT., 851/73: 1-1, 10 Mayıs 1904).

Osmanlı hükümeti kumarı ortadan kaldırmak için vilayetlere çeşitli zamanlarda kumarın men edilmesiyle ilgili uyarılar göndermekte idi. Bu yazılarda kumarın önlenmesi için alınacak önlemler sıralandı. Kumarbazlığın şer'an ve kanunen yasak olduğu, padişahın da kumarın yasak olduğuna dair bir iradesinin var olduğu hatırlatıldı. Kumar yüzünden birçok servetin yok olduğu, kumarın kesin ve kat'i olarak men edilmesi ve kumara göz yuman görevlilerin tereddüt edilmeksizin haklarında gerekli işlemin başlatılması istendi. Kumar vesilesiyle toplantı yapılmasına meydan vermemek için kahvehane, gazino ve otel gibi umumi yerlerin ve hanelerin sivil polis olarak da ifade edilebilecek hafiye memurları tarafından sık sık kontrol ettirilmesi, kumar oynandığı tespit edilen yerlere de gerekli cezaların verilmesi istendi (BOA, Y.PRK.BŞK., 68/80: 1-1; 29 Mart 1903; DH.MKT., 908/37: 22, 7 Kasım 1904; DH.MKT., 908/37: 5-1, 8 Kasım 1904). Öte yandan polis müdüriyeti pazarlarda, hamamlarda, mesire yerlerinde ve gazinolarda kumar oynayan ya da kumar oyunları bahanesiyle yankesicilik ve hırsızlık yapan hırsız kumarbazlara karşı halkı uyarmaktaydı (Sirkatler 1336: 339).

Alınan önlemlere rağmen kumar öyle bir hale geldi ki Galata'da bulunan meyhane ve kahvehanelerde alenen oynatılmaya başlandı. Hatta buralarda fuhuş da son derece yayıldı. Belgelere göre kamuoyu, kumar ve fuhuşun yaygınlaşmasından polisi sorumlu tutmakta idi. Kolluk kuvvetlerinin ihmali ve gerekli denetimi yapmamaları nedeniyle kumarın yaygınlaştığı yapılan şikâyetlerde dile getirildi. Bu konuda polisin görevlerini yerine getirmediğine dair dönemin basınında da yazılar çıktı. İkdam ve Osmanişer Loyd gazeteleri Galata'da bulunan kahvehanelerde alenen kumar oynandığını, Galata rıhtımında birçok meyhane pavyon ve birahanede fuhuş yapıldı̆̆ını, hayat kadınlarının bu mekanlara gelerek zabitan ve ahaliyi fuhşa sürüklediklerini bildirdi ve Galata Polis Merkezi'nin durumu bilmesine rağmen harekete geçmediğini, bu ahlaksızlığa göz yumduğunu ifade etti (BOA, DH.EUM.KADL., 2/52: 3, 25 Aralık 1910).

Alınan tedbirlere rağmen kumarın yaygınlaşması engellenemedi. 1914 yılında I. Dünya Savaşı'nın başlaması ile artan sosyal ve ekonomik sorunlar kumarın aleni hale gelmesinde etkili oldu. İttihat ve Terakki Hükümeti kumarın ciddi boyutlara ulaştığının farkındaydı. Bu nedenle kumar illetinin önlenmesi için özellikle de kumar oynayan memurlara yönelik cezalar artırıldı. 


\section{I) KAHVEHANELERDE VE DİĞER MEKÂNLARDA KUMAR}

\section{a) Kahvehanelerde Kumar}

I. Dünya Savaşı yıllarında toplumda birçok kesim yoksulluk içine düşmüş idi. Savaş yıllarında geçim derdi ve değişen ahlakî değerler kumarın yaygınlaşmasını beraberinde getirdi. Özellikle 1917 Rus Devriminin ardından İstanbul ve kısmen diğer Osmanlı şehirlerine Rus göçmenlerin gelmesiyle eğlence hayatı canlandı. Buna bağlı olarak kumar, fuhuş ve içki gibi problemler daha da yaygınlık gösterdi (Toprak, 1987, s. 31-32; Temel, 1998, s. 27-28). Rus göçmenler bar, pastane, lokanta, kumarhane gibi eğlence hayatının önemli mekanlarını işletmeye başladı. Bu durum İstanbul'da bu işle meşgul olan kesimlerin işsiz kalmasına neden oldu (Temel, 1998, s. 27-28). Bununla birlikte savaş döneminde spekülatif girişimler nedeniyle Osmanlı toplumunun geleneksel gelir paylaşımı da ciddi bir değişime uğradı. Yeni harp zengini bir sınıf doğdu. Gelirin el değiştirmesiyle toplumun büyük bir kesimi yoksulluk içine düşü. Yeni harp zenginleri ise sefahata sürüklendi. Savaş nedeniyle erkeklerin cepheye sevki kadınların geçim sıkıntısına düşmesine, buna bağlı olarak da fuhuş ve kumarın artmasına zemin hazırladı (Toprak, 2012, s. 545-546; Temel, 1998, s. 27-28).

Talat Paşa'nın sadrazamlığındaki İttihat ve Terakki Hükümeti, kumarın toplumsal bir bela haline geldiğinin farkındaydı. Bu nedenle savaş sırasında halk arasında kumarın yaygınlaşması hükümeti çeşitli tedbirler almaya sevk etti. Sadrazam Talat Paşa fuhuş ve kumarın yaygınlaşmasına sebep olan usulsüzlükler üzerine gitti. Otel ve pansiyonlarda ikamet edenlere dair kayıt defterlerinin bulundurulmamasını haber alması üzerine bununla ilgili talimatlar gönderdi. Örneğin 20 Mayıs 1918'de İzmit Mutasarrıflı̆̆ına gönderdiği telgrafta Adapazarı'nda otel ve pansiyonlarda ikamet edenlerle ilgili kayıt defterlerinin tutulmadığı ve buralarda alenen kumar oynandığının haber alındığını, bununla ilgili gerekli incelemelerin yapılmasını ve tedbirlerin alınmasını istedi (BOA, DH.ŞFR., 87/217: 1-1, 20 Mayıs 1918).

Sadrazam Talat Paşa'nın halk arasında kumarın yaygınlaşmasını engellemek için kahvehaneleri sıkı bir denetim altında tutma çabası da dikkate değerdir. Bu meyanda kumar oynandığı tespit edilen kahvehanelere polis baskını sıklıkla uygulanan tedbirlerden birisi idi. Ancak bu baskınlar kahvehane işletenlerin geliştirdikleri teknikler sayesinde önceden haber alınınca akamete uğrayabilmekte idi. Şöyle ki, kahvehaneye bir gözcü konulur, bu gözcü polislerin baskına geldiğini görünce haber verir ve böylece baskın sırasında kumarcıların kaçtıkları görülürdü. Örneğin 15 Eylül 1917 tarihli bir polis zabıt varakası buna örnek gösterilebilir. Bu varakada Atik mahallesinde Değirmenci Hasan adlı bir kişiye ait kahvehanede kumar oynandığının haber alınması üzerine yapılan baskına ilişkin veriler yer almaktadır. Zabıt varakasından elde edilen bilgiye göre, polis kahvehaneyi bastığı sırada kahvede Said oğlu Hasan, kardeşi Ahmed ve Sarı Mustafa oğlu Hasan adlı şahısların kumar oynamakta oldukları anlaşıldı. Ancak kahveci Hasan'ın kahvehanenin arkasında gözcü olarak çalıştırdığı Çolak Mustafa'nın baskın sırasında kumarcıları haberdar ettiği kahvehanede bulunan kişiler tarafından ifade edildi. Bu gözcülük sayesinde kumarcılar da ortadaki paraları kaldırarak firar etti. Polis zabıt varakasından anlaşıldı̆̆ı üzere Polis Memuru Ahmed Sami, Polis Komiser Muavini Ali Şamil kahvehanede bulunan kişilerden Baki Mehmed ile Ali oğlu Mehmed adlı kişilerin şahitliklerine başvurdu. Onlar da baskın sırasında kahvehanede bulunan bazı şahısların kumar oynadıklarını, esasen kahvehanede her gün kumar oynandığı ve para döndüğünü doğruladı (BOA, DH.EUM.ADL., 48/19: 1, 15 Eylül 1917). 
Bu dönemde kumarın yaygınlaşması matbuatta da geniş şekilde yer aldı. Örneğin Servet-i Fûnun gazetesinin 27 Aralık 1917 tarihli nüshasında yer alan "Muhasebe Kumar Meselesi" başlıklı yazıda Meclis-i Mebusan'da oyun kâğıtlarından alınacak rüsum hususunun tartışılması sırasında kumar meselesinin gündeme geldiği belirtilmektedir. Habere göre, Meclisteki tartışmalarda kumarın İstanbul'da akla hayale gelmeyecek ölçüde arttığı ve yüksek kumarlar oynandığı dile getirildi. Mecliste ayrıca kumarın işret gibi bir ihtiras olduğu, harp zenginlerinin az zamanda çok para kazanmaları nedeniyle servetlerini keyf ve ihtiraslara göre hazırladıkları, yüksek kumarlar oynayarak yeni zenginlerin ve onları taklit edenlerin bu belaya düştükleri dile getirildi. Yazıda kumarın men'i için zorlayıcı kanunlara müracaat etmenin, ikametgâhlara girerek kumar oynayanları tutuklamanın artık bu devirde yeterli gelmediği, vaktiyle işret aleyhinde uygulanmış olan kudretli tedbirlerin bu belayı kaldırmada yeterli olmadığı ifade edildi (Musahabe Kumar Meselesi, 1333, s. 342).

Yeni Mecmua'nın 15 Ağustos 1918 tarihli nüshasında Necmeddin Sadık tarafından kaleme alınan "Hafta Musahabesi Kumar" başlıklı yazıda ise her memlekette kumarın oynandığını, fakat hiçbir memlekette paralı talih oyunlarının bu kadar aşırı bir hal almadığı dile getirildi. Dahiliye Nazırı'nın kumarı yasakladığına değinen yazar, kumarın büyük bir istila kuvvetiyle git gide büyüdüğü ve tehlikeli bir hastalık olmaya başladığına dikkat çekti. Necmeddin Sadık yazının devamında şunları ifade etti; "artık memlekette her kulüp hatta her ev kumarhane oldu. Dört kişi bir araya geldi mi hemen kare teşkkül ediyor. Kâğıtlar fişler meydana çıkıyor kadın erkek "hele kadınlar" dokuzdan doksana kadar eli kâğıt tutanlar hep oynuyor. Yeni yetişen nesil evvela pokeri sonra bakarayı talim ediyor. Bu iptilanın daha çirkin tezahürleri de var: arkadaşlarımdan bir muallim, en mutena bir mektebimizde, ders zamanları arka sıralarda iskanbil oynandı̆̆ını yana yakıla hikaye ediyordu. Masa başına kadar sabredemeyip de vapurda liralık beş liralık, kâğıtların numerolarıyla bakara oynayanları gözümle gördüm" (Necmeddin Sadık, 1918, s. 1).

Mütareke döneminde ramazan ayı içerisinde de kumarın yaygınlaşmasını önlemek için özel tedbirler alındığı görülür. Ramazan ayının kutsallığından dolayı bu dönemde kumar gibi şer'i ve kanuni olarak yasaklanmış fiillerin engellenmesi için uyarılar yapıldı. Dahiliye Nezareti oruçlarını bozup camileri terk ederek kumar oynayanlar hakkında ramazan dolayısıyla ceza uygulanacağıyla ilgili beyannameler yayınladı. Bu beyannamelerde, Harb-i Umumi'deki yenilgi ve mevcut yaşantının herkesin malumu olduğu, mübarek ramazanda uyulması gereken farzlar bulunduğu hatırlatıldı. Ardından bazı Müslümanların emirlere aldııış etmeden oruçlarını bozarak ve geceleri camilere koşup Allaha dua etmek yerine, kahvehanelerde toplanarak oyun ve kumar oynamakla vakit geçirmekte oldukları belirtildi. Bundan dolayı orucunu bozanlar, oyun ve kumar oynayanlar hakkında kanun hükümlerinin uygulanacağı, gerekli tebligatın yapılacağı, kahvehanelerin namaz vakitlerinde kapatılacağı, kıraathane ve kahvehane işleten kişilerin bu yasaklara uymaması durumunda kanunun gereğinin yapılacağı ve bu mekânların bayrama kadar tamamen kapalı tutulacağı ifade edildi. Beyannamenin sonunda nezaretin bu mekanları bizzat teftiş edeceği bildirildikten sonra "Cenab-ı Hak bizleri selamete çıkarır ve felah oluruz" duasıla beyannameye son verildi (BOA, DH.İ.UM., 19-7/1-34: 2-1, Mayıs/Haziran 1919).

Dahiliye Nezareti'nin yayınlamış olduğu bu beyannameye ilişkin uygulamalar kahvehane işletenlerin şikayetlerine sebebiyet vermekteydi. Örneğin Eskişehir'de kahvehane işleten İran tebaasından Ali Ahraz adlı kişi Dersaadet İran Sefareti'ne şikayet mektubu göndererek, hiçbir meşru sebep yokken Eskişehir Mutasarrıfı tarafından akşam saatlerinde 
kahvehanesinin arandığını, kahvehaneye ceza yazıldığını, şahsi ve ticari hukukuna zarar verildiğini bildirerek hukukunun muhafaza edilmesini istedi (BOA, DH.İ.UM., 19-7/1-34: 51, 12 Haziran 1919). Yine Eskişehir'de kahvehane işleten İran tebaasından Şerhamet ve oğlu Ali Ekber de Dersaadet İran Sefareti'ne telgrafla şikayette bulunarak herhangi bir sebebi olmaksızın jandarma birliğiyle kahvehanesinin basıldığını, müşteriler huzurunda kahvehane edevatına el konularak 20 lira ceza kesildiğini ve kahvehanenin kapatıldığını bildirerek hukukunun korunmasını talep etti (BOA, DH.İ.UM., 19-7/1-34: 4-1, 12 Haziran 1919).

Dahiliye Nezareti bu kişilerin şikayetlerini Eskişehir Mutasarrıflığına bildirdi. Eskişehir Mutasarrıfının Dahiliye Nezareti'ne gönderdiği cevabi yazıda, yayınlanan beyannamenin gereği olarak Harb-i Umumi'de yenilgi alınmış olması nedeniyle milletin kalbinin rencide olduğu, halkın bu durumun düzelmesini arzu ederken bazı kişilerin dinî vazifelerini önemsemeden kahvehanelerde kâğıt, tavla ve tombala gibi oyunlar oynayarak kumarbazlıkla vakit geçirdiklerinin görüldügü bildirildi. Dahiliye Nezareti'nden gönderilen beyanname gereğince ne suretle olursa olsun kahvehanelerde oyun oynanmasinın yasaklandığı, bu yasağın bütün memurlara tebliğ edildiği belirtildi. Ali Efendi'nin kıraathanesinde oyunla vakit geçirildiğinin görüldüğü, bu hususta uyarıldığı, ancak ihtarın kesinlikle dikkate alınmadığı ve oyuna devam edildiği, bunun üzerine şer'i kuralları ve beyannameyi dikkate alarak kıraathanenin kapatılması emrinin verildiği dile getirildi. Ancak mutasarrıfın belirttiğine göre kıraathanenin kapatılması emrini verdiği halde kıraathane kapatılmadı. Kıraathanenin asıl işletmecisi İbrahim Rıza Bey müracaat ederek kahvehanedeki bu durumdan haberinin olmadığını, beyannamenin esaslarına uyacağını, kıraathanesinde oyun oynanmasından kendisinin de hoşnut olmadığını belirtmesi üzerine kahvehanenin kapatılmasından vazgeçildi (BOA, DH.İ.UM., 19-7/1-34: 3-1, 21 Ağustos 1919).

Kumar oyunları ve bu oyunlar sırasında çıkan tartışmalar cinayet gibi büyük suçlara da sebebiyet vermekteydi. Örneğin 1 Ocak 1916 tarihli olup Kütahya Mutasarrıflığından Dahiliye Nezareti'ne gönderilen yazıda, Kütahya'nın Hamidiye mahallesinde bir dügün evindeki sekiz kişinin içki içtikten sonra kumar oynadığı, bu sırada aralarında geçen bir münakaşa sırasında Kel İzzet adlı kişinin elinde bulunan kama ile Sultanbağı mahallesinden tebdil-i hava efradından olan Hüseyin Çavuş adlı kişiyi yaralayarak katl ettiği bildirildi (BOA, DH.EUM. 5. Şube, 20/19: 1, 1 Ocak 1916). Keza 29 Mart 1919'da Dahiliye Nezareti'ne gönderilen diğer bir belgede ise, Burdur'un Yenice mahallesinde Rum Kahveci Todori, Hacı Bedrosoğlu, Pekmezcioğlu Anton ve Hacı Mihailoğlu Stefan'ın kumar oynamakta iken aralarında çıkan münakaşa sonrasında birbirlerini yaraladıkları ifade edilmektedir (BOA, DH.EUM.AYŞ., 2/30: 1, 29 Mart 1919).

\section{b) Hapishanelerde Kumar}

I. Dünya Savaşı sürecinde hapishanelerde de kumar oldukça yaygındı. Bazı mahkûmlar gardiyanlarla anlaşarak hapishanenin koğuşlarında kumar oynamakta idiler. Hapishanelerde kumarın önüne geçebilmek için çeşitli tedbirler alınmaya çalışıldı. Ancak kumar oyunlarının men'i meselesi Dahiliye Nezareti'ne bağlı bir husus olduğundan bununla ilgili tedbirlerin hangi kurum tarafından alınması gerektiği bir süre tartışıldı. Dahiliye Nezareti Mebani-i Emiriye ve Hapishaneler İdaresi tarafından İstanbul Vilayeti'ne gönderilen tezkerede, hapishane dahilinde olan bütün hususlarda birinci derecede tedbir alması gereken kurumun Hapishane Müdüriyeti olacağı, ikinci sorumlunun vilayet olacağı, inzibati tedbirler için nezaretin meşgul olamayacağı bildirildi (BOA, DH.MB.HPS., 77/6: 1-1, 
13 Mayıs 1917). Hapishanelerde kumardan yakalanan kişilere verilecek cezanın yanı sıra kumarda kazanılan paranın ne olacağına ilişkin de bir düzenleme yapıldı. Buna göre kumardaki paranın üçte birinin muhacirlere, bir kısmının kumar oynayanları yakalayan kişilere ve kalan paranın da mal sandıklarına gelir kaydı yapılması düşünüldü (BOA, DH.MB.HPS., 77/6: 2-1, 2, 14 Mart 1917).

Hapishanelerde kumarın yaygınlaşmasının önemli nedenlerinden birisi gardiyanların kumar oynanmasına müsamaha göstermesidir. Mesela 29 Ağustos 1914 tarihli olup Dahiliye Nezareti Hapishaneler İdaresi tarafından İstanbul Vilayeti'ne gönderilen yazıda hapishanede dört yıl boyunca gardiyanlık yapan İbrahim adlı gardiyanın mahkumlarla ilişki kurduğu, hapishanenin belli bölümlerindeki koğuşlarda kumar oynanmasına göz yumduğu, vazifesine gerekli özeni göstermediği ve bu nedenle işten el çektirildiği bildirildi (BOA, DH.MB.HPS., 90/61: 1-1, 2-1, 9 Temmuz-29 Ağustos 1914).

Hapishanelerde kumarın yaygınlaşması sadece İstanbul için geçerli değildir. Taşra hapishanelerinde de kumar oynandığı anlaşılmaktadır. Örneğin Canik Mutasarrıflığından Dahiliye Nezareti'ne gönderilen 15 Nisan 1918 tarihli belgede, Hasan oğlu Mevlüd ile Salih oğlu İsmail adlı mahkumların hapishanede kumar oynamaları, hapishane asayişini ihlal etmeleri nedeniyle kalan cezalarını çekmek üzere Tokat hapishanesine nakledildikleri görülmektedir (BOA, DH.MB.HPS.M., 33/31: 1-1, 15 Nisan 1918).

Mütareke döneminde ise hapishanelerde kumarın daha yaygın hale geldiği anlaşılmaktadır. Hapishanelerde kumar o kadar ciddi boyutlara ulaştı ki, bu sebeple çıkan kavgalarda cinayet olayları dahi yaşandı. Dahiliye Nezareti Hapishaneler Müdüriyeti, İstanbul'da hapishanelerde kumar yüzünden kavga çımasının ve cinayet işlenmesinin önüne geçebilmek için gerekli tedbirlerin alınmasını istedi. Örneğin 1920 yılının Ramazan ayının on ikinci günü İstanbul hapishanesinde yaşanan bir olay buna örnek gösterilebilir. Hapishanede çıkan bir olayda bir mahkûm silahla katledildi ve birkaç mahkum da yaralandı. Olay incelendikten sonra mahkûmların karantina koğuşunda kumar oynarken bir anlaşmazlık sonucunda kavgaya tutuştukları anlaşıldı. Kavgada Arap Mehmed adlı mahkûm elindeki bıçakla Çorlulu Ziya adlı mahkûmu sol tarafından yaralayarak öldürmüş idi. Bu olay üzerine hapishanede yapılan arama sonucunda tabanca, kama, bıçak, sustalı çakı, kaşık, bıçak, çatal, esrar gibi maddeler bulundu. Ancak tabancanın hapishaneye nasıl sokulduğu anlaşılamadı (BOA, DH.MB.HPS., 99/8: 1-10, 30 Eylül 1920).

$\mathrm{Bu}$ olay üzerine hapishanelerin incelenmesi ve 1 slah edilmesi için müfettiş görevlendirildi. Müfettişler hapishanede inceleme yaparak kumarın engellenmesi için yapılması gerekenlere dair rapor hazırladı ve Dahiliye Nezareti'ne sundu. 29 Eylül 1920 tarihli raporda kumarın yaygınlığını hapishane dahilinde kumar oynanmasına imkan sağlayan koğuş gardiyanlarından ve hapishane inzibat memurlarından kaynaklı olduğunu söylemenin yetersiz olacağı, kumarın engellenmesi için hapishanedeki genel güvenlik koşullarının iyileştirilmesinin şart olduğuna dikkat çekildi (BOA, DH.MB.HPS., 99/8: 9-1, 29 Eylül 1920).

Kumar oynadığından dolayı nezarete alınan bazı kişilerin nezarethanede de sorun çıardıkları görülmekte idi. Örneğin 11 Haziran 1919 tarihli zabıt varakasında belirtildiği üzere, kumar oynamaktan dolayı nezarete alınan Karaağaç mahallesi sakinlerinden yirmi iki yaşında Cemal oğlu Naci Efendi, başını ve vücudunu duvarlara ve masalara vurarak taşkın hareketlerde bulundu. Ayrıca etrafında bulunan kişilere ve memurlara saldırarak zarar 
verdi. Naci Efendi nezarete alındığı sırada üzerinde asker elbiseler bulunuyordu. Polis Memuru İhsan Fazıl Bey'in asker elbiselerini nereden bulduğuna ilişkin sorusu üzerine kendisinin sorguya çekilemeyeceğini, asker olduğunu ve kumandanının bulunduğunu belirtti. Kumar suçuyla nezarete alınan Naci, burada polis memurlarına ve mevcut hükümete karş1 kötü sözler de sarf etti (BOA, DH.EUM.AYŞ., 66/24: 1, 3, 11 Haziran 1919). Polis sorgusundan sonra anılan kişinin bir dolandırıcı olduğu anlaşıldı. İşkodra'da öğrenci olduğunu ifade etmekle birlikte uzun yıllardır hiçbir iş yapmadan insanları dolandırarak ve barakasında kumar oynatarak kumarbazlıkla işini yürüttügü ortaya çıktı. Naci Efendi'nin üst düzey memurlarla ilişki kurarak işlerini kolaylıkla hallettiği de anlaşıldı. Kumarbaz Naci, öncelikle sağlık muayenesinden geçirildi bilahare Hüdavendigar Vilayeti'nin idare-i örfiye mintıkasında bulunması nedeniyle Eskişehir'e gönderildi (BOA, DH.EUM.AYŞ., 66/24: 1, 3, 5, 7, 11 Haziran 1919).

\section{c) Diğer Mekânlarda Kumar}

I. Dünya Savaşı sürecinde kumar ve fuhuş toplumu tehdit eden büyük bir soruna dönüşmüş idi. Fuhuş ve kumarın bu boyutlara ulaşması şüphesiz savaşın getirdiği ekonomik ve siyasi buhran ve travmadan kaynaklı idi. İnsanlar geçim sıkıntısı çekiyordu ve yoksulluk artmıştı. Savaş sonrasında geçim derdi daha da arttı. Bu nedenle geçim temin etmek için ahlakî olmayan yollar tercih edilmeye başlandı. Bu nedenle Mütareke döneminde özellikle İstanbul'da kumar aleni hale geldi (Toprak, 1987, s. 31-32).

Bu dönemde halk arasında kumar oyunlarının çeşitliliği söz konusudur. I. Dünya Savaşı süresince özellikle İstanbul'da çeşitli kumar türleri yaygınlık gösterdi. "Hoppala" adı verilen kumar oyunu da bunlardan birisi olup özellikle Beyazıt civarlarında izinsiz olarak oynatılmakta idi. Örneğin İstanbul Polis Müdüriyeti Umumiyesi'nden Dahiliye Nezareti'ne gönderilen 24 Haziran 1919 tarihli yazıda Beyazıt'ta Maliye Nezareti karşısında bulunan mahallerde Hasan Efendi adlı bir şahsın "hoppala" adı verilen bir kumar oyununu oynattırdığ 1 ifade edildi. Bunun üzerine Beyazıt polis merkezi tarafından duruma müdahale edildi ve kumar oyununa ait on bir kalem eşya müsadere edilerek emanet dairesine gönderildi (BOA, DH.EUM.AYŞ., 13/52: 1, 24 Haziran 1919).

Kumarın aleni olarak oynanmasında İtilaf devletlerinin keyfi tutumu da etkili olmakta idi. İtilaf devletleri komiserliklerinin bu konudaki kayıtsız tutumları işletmecilere cesaret vermekte idi. Osmanlı kolluk kuvvetlerinin bu dönemde yaptırım uygulamakta sıkıntılar çekmesi de kumarı aleni hale getirmekte idi. Örneğin 20 Eylül 1921'da Dahiliye Nezareti tarafından gönderilen bir yazıda ifade edildiğine göre; Beykoz parkı civarında bulunan bazı gazinolarda alenen kumar oynatılması nedeniyle Polis Müdüriyeti bu mekanlara müdahale etmiş idi. Ancak gazino sahipleri buna itiraz ederek hükümetle yapılan mukavelename gereğince kumar oynatmaya salahiyetleri olduğunu iddia ettiler. Bunun üzerine Osmanlı makamları mukavelenamenin suretini görmek istedi, ancak işletme sahipleri mukavelenamenin kendilerinde bulunmadığını belirtti. Mukavelenin bulunması için makamlar arasında uzun süren yazışmalar olumlu bir sonuca ulaşmadı (BOA, DH.İ.UM., 1921/1-68: 1-1, 2-1, 20 Eylül 1921).

Polis Müdürü Umumisi Miralay Salih Bey, 31 Ağustos 1921'de Dahiliye Nezareti'ne gönderdiği yazıda Polis Müdüriyeti'nin Beykoz parkında alenen oynanan kumar oyunları için tedbir almaya çalıştığı, ancak Beykoz parkında işletme sahibi olan kişilerin hükümetle yaptıkları mukavelename esasları gereği oyun oynatabileceklerini iddia ettikleri, bu nedenle hiçbir tedbir alamadıkları, mevcut mukavelenamenin içeriğinin bildirilmesini talep etti. Öyle 
anlaşılıyor ki bu hususta İstanbul Polis Müdüriyeti oldukça sıkıntı yaşadı. Kumar yasak olmasına rağmen alenen kumar oynanmakta idi ve polis mukavelenameyi göremediği için bununla ilgili işlem yapamamaktaydı (BOA, DH.İ.UM., 19-21/1-68: 6-1, 31 Eylül 1921). Bunun üzerine Beykoz merkez memurluğu, kumar oyunlarının men edilmesiyle ilgili Üsküdar semtinden gelen tezkereye atıfta bulunarak gerekli tedbirleri alma yoluna gitti (BOA, DH.İ.UM., 19-21/1-68: 3-6, Eylül 1921).

Beykoz'da bulunan oyun salonlarında kumar oynatılması meselesi Meclis-i Vükela gündemine de alındı. Ağustos 1922 tarihli bir Meclisi Vükela oturumunda Beykoz'daki oyun salonlarının kapatılması ile ilgili İstanbul Vilayeti'nce alınan karar müzakere edildi. Şöyle ki, İstanbul Vilayeti Defterdarlığı, Osmanlı toprakları dâhilinde kumar oyunlarının kanunen yasak olmasına binaen Beykoz gazinosundaki oyun salonlarının kapatılması ile ilgili bir karar vermiş idi. Gazino sahibi Mösyö Perder, bu uygulamanın şirketin imzaladığı mukavele şartlarına aykırı olduğunu ve "oyun" tabirinin kumar olarak adlandırılamayacağını bildirerek duruma itiraz etti. Bunun üzerine şirketin mukavelenamesinde "oyun" olarak ifade edilen tabirin kumar olup olmadığının tefsirine ihtiyaç duyuldu ve Meclis-i Vükela'ya başvuruldu. Meclis-i Vükela konuyu müzakere etti ve mukavelenamedeki oyun tabirinin kumar şeklinde tefsir olunmasının mümkün olamayacağını ancak bunun "yasaklanmış lubiyat" olarak anlaşılabileceği kararına vardı. Ayrıca şirket mukavelenamesinin dokuzuncu maddesinde yer aldığı şekliyle şirket ve vilayet arasında ortaya çıkacak itilafların Osmanlı mahkemeleri tarafından görüleceği esası hatırlatıldı. Kararın Hariciye Nezareti aracılığıyla İtilaf devletleri komiserliklerine bildirilmesi kararlaştırıldı (BOA, MV., 224/59: 1-1, 15 Ağustos 1922).

Mütareke döneminde kumarın bir türü olarak tombala da önemli bir sorun haline geldi. 6 Nisan 1921 tarihli Meclis-i Vükela'da tombalanın İslam mahallerinde yasaklanmasıyla ilgili bir görüşme yapıldı. Zira bu dönemde İstanbul'da kahvehane, gazino gibi birçok umumi yerde "tombala" oyunu oldukça yaygındı. Bu oyunun yaygın hale gelmesinde Rus mülteciler etkili oldu. Rus mültecilere İtilaf devletleri zabıtası tarafından ruhsat verildiği için Osmanlı Devleti'nin tombala oynatanlar hakkında adli takibat yapması ve kanunları uygulaması mümkün olamamakta idi. Ancak bilahare tombala lûbiyatı ahlaken ve iktisadi olarak birçok zarara sebep olduğundan tombalanın yaygınlaşmasını engellemek için bazı tedbirler alınması zorunlu görüldü. Bu durum Adliye Nezareti tarafından bir tezkere ile Meclis-i Vükela'ya bildirildi. Meclis-i Vükela'nın tombala ile ilgili olarak aldığ1 karar ise şu şekildedir; tombala ahlaka ve servete ciddi zararlar vermektedir ve şerî̀ olarak da yasaktır. Bunun men edilmesi esasen hükümetin vazifesi olmakla beraber tombalanın icra edilmesine müsaade edenler İtilaf devletleri zabıtasıdır. Hal böyle olunca tombalanın genel olarak yasaklanması zor görünmektedir. Bu nedenle tombalanın sadece Beyoğlu civarında oynanması, diğer yerlerde ve özellikle İslam mahallerinde tombala oynatılmaması kararı alındı. Keza Osmanlı zabıtasının bu konuda yardımının sağlanabilmesi için Hariciye Nezareti'nin İtilaf devletleri temsilcileri nezdinde girişimde bulunması ve Adliye Nezareti'ne bilgi verilmesi karara bağlandı (BOA, MV., 221/102: 1-1, 6 Nisan 1921). 


\section{II) DEVLET MEMURLARININ KUMAR ALIŞKANLIKLARI VE DEVLETIN ALDIĞI TEDBİRLER}

I. Dünya Savaşı yıllarında kumar illeti devlet memurları arasında da yaygınlık kazanmış idi. Devlet memurlarının kumar oynamalarına ilişkin şikâyetlerin artması üzerine hükümet her düzeyde devlet memurunun kumar alışkanlıklarını ortadan kaldırmak ya da engellemek için ciddi tedbirler aldı. Devlet memurlarının kumar oynamalarının men edilmesi devlet için kumarın halledilmesi anlamına geliyordu. Zira Servet-i Fünun gazetesinin 27 Aralık 1917 tarihli nüshasında yer alan "Muhasebe Kumar Meselesi" başlıklı yazıda Meclis-i Mebusan'da oyun kâğıtlarından alınacak rüsum hususunun tartışılması sırasında kumar meselesinin gündeme geldiği sırada Maliye Nazırı'nın bunu ahlaki bir mesele olarak telakki ettiği ifade edilmektedir. Maliye Nazırı kumarın ortadan kaldırılması için genel ahlak seviyesinin yükseltilmesinin gerekli olduğunu, bu derdin devasının bulunduğunu, hükümet memurları arasında kontrolün artırılması gerektiğini, kumarbaz memurların azaltılmasıyla meselenin çözülebileceğini dile getirdi (Musahabe Kumar Meselesi 1333: 342).

Bunun üzerine kumar oynayan memurlara yönelik ciddi yaptırımlar uygulandı. Özellikle yurt dışında bulunan Osmanlı diplomatlarının kumar oynamaları yasaklandı ve kumar illetine bulaşan diplomatların işlerinden el çektirileceğine dair tamimler yayınlandı (BOA, HR.SFR.04, 650/51: 1-1, 1-2, 23 Mart 1916).

\section{a) Yurt Dıșında Görevli Memurların Kumar Alıșkanlıkları}

Yurt dışındaki Osmanlı diplomatlarına kumarın yasak olduğu ile ilgili gönderilen tamimler burada yaşanan olaylarla yakından ilgilidir. Çünkü bu dönemde bazı elçilik görevlileri kumar alışkanlıkları nedeniyle görevini yapamaz hale geldi. Üstelik kumar borçları nedeniyle devleti zor duruma düşürüldü. Bunlardan birisi eski Roma ve Washington Sefiri Kazım Bey'in oğlu olup Sofya Sefareti üçüncü kâtip vekâletinde görevli Nazif Bey idi. Nazif Bey'in, Sofya'da bulunduğu sırada kumar oyununa müptela olduğu anlaşılmakta idi. Kumara devam etmesi halinde meslekten men edileceğine dair yapılan uyarılara rağmen oynamaya devam etti. Hatta Nazif Bey bir gecede yüklü miktarda para kaybetmesine rağmen kumardan vazgeçmedi. Bu durum üzerine Sofya Sefareti sorunu Hariciye Nezareti'ne bildirdi ve Nazif Bey'in Sofya'daki borçlarının ödenmesi için son maaşının Sofya'ya gönderilmesini talep etti (BOA, HR.SFR.04, 650/51: 1-1, 1-2, 23 Mart 1916).

Bu vaka örnek bir durum oluşturdu. Bu olayın ardından Hariciye Nezareti tarafından elçiliklere gönderilen yazıda, kumar oyununun mahzurlu neticelere sebep olduğu, Hariciye memurlarının bu gibi alışkanlıklar sonucunda maruz kalacakları zorlukların gerek kendi şereflerini gerekse devletin haysiyetini ve itibarını sarstığına dikkat çekildi. Nazif Bey'in yaşattığı bu olayın dikkate alınmasının zorunlu olduğu, genç Hariciye memurlarının kumar oyunlarına kapılmadan mesleklerinde tam bir başarı kazanmak için çalışmaları gerektiği vurgulandı. Bu meyanda Hariciye memurları ve şehbenderlerin briç, pikye, 1skarta gibi oyunlar müstesna olmak üzere bakara, poker, rulet vb. oyunlar oynamalarının katiyen yasak olduğu, oynayanların memuriyetten el çektirileceği bildirildi (BOA, HR.SFR.04, 651/83: 2-1, 2 Nisan 1916; HR.SFR.04, 902/17: 1, 2 Nisan 1916).

Keza Hariciye Nezareti tarafından Sofya Sefiri Fethi Bey'e gönderilen 11 Nisan 1916 tarihli yazıda, 2 Nisan 1916 tarihinde gönderilen tahrirata ekleme yapıldı. Buna göre, eski Roma Sefiri Kazım Bey'in oğlu olan ve bir sene evvel Sofya Sefareti üçüncü katipliğine tayin 
edilen Nazif Bey'in burada kumara alışması, bu alışkanlığını ısrarla sürdürmesi, bir gecede 50 bin levata kaybetmesi, meblağ ödeyememesi sonucunda haysiyetini ve resmi vazifesini şaibeli duruma düşürmüş olmasından dolayı bir daha diplomasi mesleğinde istihdam edilmemek üzere memuriyetten azl edildiği bildirildi (BOA, HR.SFR.04, 651/83: 4-1, 11 Nisan 1916) ${ }^{1}$.

Diplomatlar dışında çeşitli nedenlerle yurt dışına gönderilen memurlar arasında da kumar alışkanlığı görülmekte idi. Mesela yurt dışına tedavi amacıyla giden bazı askeri memurların gittikleri yerlerde kumara müptela oldukları anlaşılmaktadır. Ordu-yu Hümayun Başkumandanlığı Vekaleti tarafından Emniyet-i Umum Müdüriyetine ve Zaptiye Nezareti'ne gönderilen belgeler buna örnek gösterilebilir. Mesela Siverek Mebusu Nurettin Bey'in oğlu İhtiyat Mülazımı Atıf Bey, savaş yıllarında tedavi için İsviçre'nin Davos sanatoryumuna gönderilmiştir. Atıf Bey'in Davos'ta otelde kaldığı süre içerisinde kumar ve sefahata düştüğüne dair bir istihbarat alınmıştır. Başkumandanlık Atıf Bey'in İstanbul'a dönmesini istemektedir. Ancak alınan istihbaratın doğru olup olmadığı hususunda Emniyet-i Umum Müdüriyetine ve Zaptiye Nezaretine bir yazı göndererek bu hususta tahkikat yapılması talep edilmiştir (BOA, DH.EUM.2. Şube, 39/24: 1, 3, 5, 7, 2 Temmuz 1917). Fakat Atıf Bey hakkında istihbaratın sonucunun ne olduğuna ilişkin veriye rastlanmamıştır.

\section{b) Devlet Memurlarının Kumar Nedeniyle Görevlerini Kötüye Kullanmalarına Bir Örnek: Halep Baron Oteli}

Alınan tedbirlere rağmen I. Dünya Savaşı yıllarında kumar oyunlarına olan ilginin artışı devleti zor durumda bırakmakta idi. Zira savaş döneminde askeri ve sivil memurlar arasında kumar borcu olanların görevlerini kötüye kullandıkları görülmekte idi. Örneğin Dahiliye Nazırı Talat Bey'den Dördüncü Ordu Kumandanı Cemal Paşa'ya gönderilen 19 Temmuz 1916 tarihli şifre bu konuda önemli veriler ortaya koymaktadır. Şifreden elde edilen bilgilere göre, Halep'te Baron isminde bir Ermeni kendi adını taşıyan Baron Oteli'ni kumarhane olarak kullanmaktadır. Otel, misafirhane olmaktan daha ziyade kumarhane işlevini görmektedir. Anılan kişi Halep'e atanan veya yeni gelen Osmanlı memurlarını bu otelde ağırlayarak onların sevgi ve itimadını kazanmak için çalışmaktadır. Memurlar burada eğlenceye, zevke ve kumara alıştıılmaktadır. Baron memurların kumar borçları için yüklü paralar vermektedir. Böylece Halep'te bulunan büyük ve küçük mevkideki memurlar otelin müdavimi haline getirilmektedir. Ermeni olan otel sahibi Ermeniler lehine çalışmak için hiçbir fırsatı kaçırmamaktadır. Talat Bey bu kişi hakkında Cemal Paşa'nın görüşünü sormuştur. Cemal Paşa tarafından gönderilen 2 Ağustos 1916 tarihli cevabi yazıda konuya ilişkin şu ifadeler yer almaktadır; Baron Oteli kumarhane ve fuhuşhane olmak hususunda Halep'teki diğer bütün otellerden farklı değildir. Baron'un şahsı ve mahiyeti hakkında Muhacirin Müdürü Şükrü Bey'in çok daha fazla bilgiye sahip olduğu dile getirildi. Cemal Paşa, Baron'un başka bir mahalle sevkinin uygun olup olmadığı hususunun ise vicdan, namusuna ve kanunları uygulamaktaki titizliğine sonsuz bir güven duyduğu Halep Valisi Mustafa Abdulhalik Bey'e sorulmasının daha uygun olacağını ifade etti (BOA, DH.EUM.2. Şube, 26/9: 1, 9 Ağustos 1916).

\footnotetext{
${ }^{1}$ Hariciye Nezareti'nin kumarla ilgili aldığı bu kararlar elçiliklere iletilmiş, elçilikler de bu durumu şehbenderliklere bildirmiştir (BOA, HR.SFR.04, 902/17: 1, 2 Nisan 1916; HR.SFR.04, 651/67: 1-1, 13 Nisan 1916; HR.SFR.04, 651/83: 1-1, 14 Nisan 1916; HR.SFR.04, 888/17: 2-1, Nisan 1916; HR.SFR.04, 903/27: 1, 3 Mayıs 1916; HR.SFR.04, 651/83: 3-3, 3 Mayıs 1916; HR.SFR.04, 902/17: 3, 14 Nisan 1916, HR.SFR.04, 902/17: 5, 14 Nisan 1916, HR.SFR.04, 902/64: 1, 14 Nisan 1916, HR.SFR.04, 902/69: 1, 14 Nisan 1916).
} 
Halep Valisi Mustafa Abdulhalik Bey Baron Oteli hakkındaki istihbaratı doğruladı. Baron'un yüksek seviyede ya da küçük mevkide olan memurlara çok iyi yaklaşarak onların itimadını kazandığı, fırsat buldukça otelinde kumar oynadığı ve kumarda yüksek mevkide bulunanların kazanmasını sağlamaya çalıştı̆̆ ifade edildi. Halep Valisi, kadın ve kumara mukavemeti olmayan memurların en nihayetinde "Baron'un rüya alemine daldıklarımı" açıkça dile getirdi. Bu memurlar arasında Halep polis müdürü de bulunmakta idi. Hafif seciyeli olan polis müdürü gece eğlencelerine hayır diyememiştir. Baron'un son derece mutaassıp bir Ermeni olduğu, Ermenilerin lehinde çalışmak için fırsat kolladığı, son Halep isyanı teşebbüsünde bilgisinin bulunduğundan şüphe edilmediği, ancak tahkikat sırasında kendisini ele verecek delil elde edilemediği belirtildi. Baron'un başka bir yere sevki durumunda, şehrin ihtiyacını karşılayan otelin İstanbul'dan veya bir başka yerden gönderilecek becerikli bir Müslüman otelci tarafından idare edilmesi gerektiği bildirildi. Ayrıca Halep'teki kumar, gece hayatı ve eğlence ortamına mukavemet edebilecek şekilde kuvvetli bir kişiliğe sahip polis müdürü bulunmasının uygun olacağı da dile getirildi (BOA, DH.EUM.2. Şube, 26/9: 7-9, 27 Temmuz 1916).

Devlet memurları ile Ermeni Baron ve oteliyle ilgili çok sayıda istihbarata rastlanmaktadır. Halep Ermeni teşkilatının merkezinin Ermeni Baron oteli olduğu, Halep'te bu otelden daha muntazam bir mekan bulunmadığı, müfettişlerin, müdürlerin ve üst düzey memurların bu otelde kaldıkları, Baron adlı Ermeni'nin kendi mülkü olan bu otele gelenlerin otelin verdiği gafletten zor kurtuldukları, otelde kumar oynayarak ve sefahatlar yaparak borçlandıkları, Baron'un bu borçları ödeyerek memurların güven ve itimadını kazandığı ifade edilmiştir. Memurların otel sahibine taltifler, takdirnameler gönderdikleri, Baron'un Ermeni komitaları için topladığı paraların mektepler için toplandığına karar verilerek aklandığı, papaz ve Baron'un otelde sürekli görüşme yaptıkları da bildirildi (BOA, DH.EUM.2. Şube, 26/9: 15). Ayrıca Baron Oteli'nde kumarbazlık ve sefahat borçları ödenmiş olan memurların verdikleri raporlara da dikkat edilmesi gerektiği vurgulandı (BOA, DH.EUM.2. Şube, 26/9: 13).

Baron oteli ile memurlar arasında yaşanan bu ilişkinin bölgedeki Ermeni olaylarına etkilerini değerlendiren istihbarat raporları da dikkatten kaçmamaktadır. Buna göre, Halep'te gayet önemli ve mükemmel bir Ermeni merkezinin bulunduğu, Anadolu'dan akın akın buraya gönderilmiş Ermenilerin en önemlilerinin para kuvvetiyle Halep'te kaldıkları, bugün itibarıyla Halep'te 15.000 Ermeni firarisi bulunduğu, Halep dışına Deyrizor ve Suriye'ye gönderilen Ermenilerin daha çok "acezelerden ve fakirlerden" oluştuğu bildirilmiştir. Halep valisi müstesna olmak üzere burada bulunan birçok memurun para aldığı, Halep'te oldukça etkili bir Ermeni teşkilatının bulunduğu ve böyle giderse eninde sonunda burada bir Ermeni isyanı patlayacağının da altı çizilmiştir (BOA, DH.EUM.2. Şube, 26/9: 16). Bu bilgiler üzerine Dahiliye Nazırı Talat Bey, Halep valisine gönderdiği emirde Baron'un sevkinin uygun olduğunu bildirdi (BOA, DH.EUM.2. Şube, 26/9: 19, 27 Temmuz 1916). Talat Bey, Dördüncü Ordu Kumandanı Cemal Paşa'ya da bir telgraf göndererek Halep'te otel sahibi Baron'un otelini bir misafirhaneden ziyade kumarhane ve fuhuşhane olarak kullandığı, büyük ve küçük mevkilerde bulunan memurları otelinde ağırlayarak saygınlık kazandığı, Ermenilerin lehinde çalışarak Ermenilerin Halep isyanından haberdar olduğu, bu nedenle Baron'un o bölgeden uzaklaştırılmasının uygun olacağını ifade etti (BOA, DH.ŞFR., 66/192: 1-1, 9 Ağustos 1916). Keza Dahiliye Nezareti'nden Halep Mutasarrıflı̆̆ına gönderilen yazıda, Baron'un hamiyet ve himayesini kazanan memurların kimler olduğunun bildirilmesi istendi (BOA, DH.ŞFR., 66/56: 1-1, 22 Temmuz 1916).

SEFAD, 2019; (41): 405-426 
c) Devlet Memurları Arasında Yaygınlaşan Kumarı Önlemeye Yönelik Hukukî Düzenlemeler

Devlet memurları arasında kumarın yaygınlaşması devlet hizmetlerinin aksamasına ve devletin itibarının sarsılmasına neden oldu. Bu durum ayn zamanda devlet güvenliğini de tehdit etmekte idi. İttihat ve Terakki Hükümeti, memurlar arasında yaygınlık kazanan kumarın engellenmesi için hukukî tedbirler alma yoluna gitti. Bu kapsamda Dahiliye Nezareti devlet memurlarının kumar oynamalarının yasaklanması hakkında bir nizamname hazırladı. Dahiliye Nazırı Talat Bey imzasıyla 16 Ağustos 1916 tarihinde ve 426 numara ile Sadrazamlık makamına yazılan bir yazıda, memurların kumar oynamaya itibar ettikleri ayrıca ticaretle uğraşmaya başladıkları, vali, mutasarrıf, kaymakam ve nahiye müdürlerinin memuriyetlerini kendi çıkarları için kullandıkları belirtilerek bu fiillerin esasen yasak olduğu, yasağa uymayanların azledilmeleri hakkında Memurin-i Dahiliye Nizamnamesi'nin 26. maddesine ilave olmak üzere bir nizamname fıkrası düzenlenerek layihanın takdim edildiği bildirildi (BOA, ŞD., 2838/30: 4-6; ŞD., 2838/30: 1-3, 16 Ağustos 1916).

16 Ağustos 1916 tarihli ve 426 numaralı tezkere ile gönderilen kanun layihası, Dahiliye Nazırı Müsteşar Yardımcısı tarafından 5 Eylül 1916 tarihinde Şura-yı Devlet'e iletildi (BOA, ŞD., 2838/30: 4, 5 Eylül 1916). Dahiliye Nezareti'nin memurların kumar alışkanlığının yasaklanması ile ilgili hazırlamış olduğu layihanın birinci maddesinde, kumar oynamak şer'an yasak ve ahlaken de kötü bir alışkanlık olarak değerlendirilmektedir. Ceza Kanununun yalnız kumar oynatmayı alışkanlık edinenlere karşı 242. maddesinde bir aydan altı aya kadar hapis ve bir mecidiye altından elli mecidiye altına kadar nakit ceza verme esasına dayandığı bildirildi.

Aynı layihada memurların kumar oynamayı alışkanlık etmeleri şer'an, ahlaken ve kanunen suç teşkil etmesinin yanında, memurların vazifelerine de engel olacağı, zira kumarın vermiş olduğu heyecanın, düşünce ve ideallerine olumsuz tesirde bulunacağı ifade edildi. Diğer taraftan layihaya göre, şer'an ve ahlaken yasak olan kumar oyununu alışkanlık edinen memurların ahali nazarındaki itibarları olumsuz etkilenecek ve bunun neticesinde temsil ettikleri devletin itibar ve nüfuzu da sarsılacaktır. Ayrıca memurların maaşları sınırlı olduğundan kumardaki zararlarını telafi etmek için oyuna devam etmeye mecbur kalacaklardır. Kumar için ihtiyaç duydukları parayı temin etmek için veya kumarda israf ettikleri maaşlarını yerine koymak için rüşvete eğilimleri görülecektir. Keza borç almak zorunda kalan memurlar, itibarlarını kaybedecek bu durum idari ve kanuni bir suç oluşturacaktır. Dahiliye Nezareti bu gerekçeleri belirttikten sonra 2 Aralık 1915 tarihli Memurin-i Dahiliye Nizamnamesi'nin 26. maddesine "memurin-i dahiliyenin kumar oynamaya i'tiyad etmeleri, ticaret icra eylemeleri veyahut kollektif ve komandit şirketler ile hissedarlık vechle olan şirkete dahil olmaları vali, mutasarrnf, kaymakam ve nahiye müdürlerinin daire-i memuriyetleri dahilinde irahe, tefrih ve nüfuz etmeleri memnudur. Hilaf-ı memnuiyyet hareket eden memurlar azl olunur" şeklinde bir fıkra ilavesini talep etti (BOA, ŞD., 2838/30: 8-16, 15 Ağustos 1916).

Dahiliye Nezareti'nin Şura-yı Devlet'e gönderdiği tezkere Tanzimat Dairesi'nde okundu ve incelendi. Şura-yı Devlet bu layihanın sadece Dahiliye Nezareti memurları için değil bütün memurları kapsayacak şekilde düzenlenmesine dair karar aldı. Bunun için memurların bağlı bulundukları nezaretlere malumat ve teklif gönderilmesi, söz konusu yasağın bütün memurlara uygulanabilmesi için nezaretlerce bir inceleme yapılarak bir layiha düzenlenmesi ve bu şekilde umumi bir nizamname hazırlanması uygun bulundu (BOA, ŞD., 2838/30: 18, 20, 22, 24, 3 Ekim 1916). 
Şura-yı Devlet'in bu kararı üzerine Tanzimat Dairesi "bilumum memurin ve müstahdemin-i devletin kumar oynamaktan ve ticaret eylemekten memnuiyetlerine vesaireye dair nizamname layihası" adıyla dört madde ve bir de geçici maddeden oluşan bir layiha hazırlandı. Layihanın ilk maddesi kumarla ilgili idi. Buna göre "Bilumum memurin ve müstahdemin-i devletin kumar oynamalar memnudur. Hilaf-1 memnuiyet hareket edenler birinci defasında amirleri tarafindan tahriren ihtar ile ve ikinci defasında bir maaşlarının kat' ile ve üçüncü defasinda memuriyetlerinden azl ile cezalandirllılar" (BOA, ŞD., 2838/30: 26, 29 Ekim 1916) hükmü yer aldı.

Tanzimat Dairesi'nin hazırlamış olduğu mazbata ve nizamname layihasının teferruatı Şura-yı Devlet heyeti tarafından görüşüldü. Kurul, Tanzimat Dairesi'nin düzenlemiş olduğu nizamname layihasına çeşitli ekler yaparak beş daimi ve biri geçici olmak üzere bir nizamname hazırlandı (BOA, ŞD., 2838/30: 28, 30, 32, 17 Kasım 1916). Bu düzenlemenin kumarla ilgili maddesi; “Bilumum memurin ve müstahdemin-i devletin kumar oynamalar memnu olub hilaf- - memnuiyet hareket edenlerin birinci defasında tevbihi, ikinci defasında tam maaş kat'ı ve üçüncü defasında da azl ile mücazaat olunurlar" şeklinde kabul edildi (BOA, ŞD., 2838/30: 38, 40, 42, 17 Kasım 1916; ŞD., 2839/12: 1, 11 Aralık 1917).

Düzenlemenin son şekli Meclis-i Vükela'da görüşüldü. Devlet memurları arasında yaygınlaşan kumarın engellenmesi amacıyla 5 Aralık 1917 tarihinde "Bilumum memurin ve müstahdemin-i devletin kumar oynamaları memnû olup hilaf-ı memnuiyyet hareket edenlerin birinci defasında tevbihini ve ikinci defasında tam maaş kat’ ve üçüncü defasında azl ile mücazat olunmalar ba-tezkere keyfiyetin tamimen devaire tebligatı kararlaşttrıldı" esası kabul edildi. Meclis-i Vükala'nın kararı 11-25 Aralık 1917 tarihleri arasında bütün devlet dairelerine bildirildi (BOA, MV., 210/78: 1-1, 5 Aralık 1917; geniş bilgi için bkz. BOA, BEO., 4495/337056: 1, 1-1, 2 , 3-2, 5 Aralık 1917; MF.MKT., 1232/37: 1-1, 25 Aralık 1917; MF.MKT., 1232/29: 1-1, 25 Aralık 1917; ŞD., 2838/30: 38, 40, 42, 4 Kasım 1917; ŞD., 2839/12: 1, 11 Aralık 1917). Keza bu karar 13 Aralık 1917 tarihinde Sadrazam Talat Paşa imzasıyla bütün vilayet ve mutasarrıflıklara da tamimen tebliğ edildi (BOA, DH.İ.UM.EK., 44/57: 1-1, 1-2, 2, 13 Aralık 1917; DH.UMVM., 124/130: 1-1, 9 Ocak 1918).

Esasen 1858 tarihli Ceza Kanunnamesinde kumarla ilgili madde bulunmasına rağmen Meclis-i Vükela neden kumarın yasaklanmasıyla ilgili tekrar bir karar çıkarmaktadır? Esasen bu durum Tanzimat Dairesi'nin memurlara kumarın yasaklanmasıyla ilgili hazırladığı layihanın mazbatasında açıça ifade edildi. Buna göre Ceza Kanunu, kumarhane açanlarla orada sarraflık suretiyle akçe veren şahıslar hakkında ceza hükümleri içerdiği halde alenen kumar oynayanlara karşı hafif veya yetersiz kalmaktadır. Kumar, uzak durulması gereken bir alışkanlıktır ve kumarın memurlar tarafından umumi veya hususi surette oynanması caiz değildir. Söz konusu yasaklamanın Askeri ve Mülki Ceza Kanunlarında yer aldığı ve bu cezaların genel hukuk kaideleriyle uyumlu hale getirilmesinin gerekli olduğu da ifade edildi (BOA, BEO., 4495/337056: 3-1, 8 Kasım 1917).

Hükümetin kumarı önlemeye yönelik uyarılarına ve yasal önlemler alma çabasına rağmen I. Dünya Savaşı sürecinde memurların kumar oynama alışkanlıkları tam olarak ortadan kaldırılamadı. Zira bu dönemde memurların kumar oynamaları ile ilgili çok sayıda şikâyetin varlığından söz edilebilir. Mesela Sivas Vilayeti'nde görevli iken kumar oynaması nedeniyle Batum'a gönderilen Ahmed Rüştü Efendi burada da kumar alışkanlığına devam etmesi üzerine memuriyetten azl edilmiş idi (BOA, DH.EUM.MEM., 60/90, 14 Şubat 1915). Keza 8 Ocak 1917'de Diyarbakır Vali Vekili Bedreddin Bey tarafından Dahiliye Nezareti'ne 
gönderilen bir yazıda, Diyarbakır İstinaf Reisi Vasıf Bey, Sulh Hakimi Sadık Efendi, Halaskâran Grubu müessislerinden olup Diyarbakır'da görevli Ferid Paşa'nın grup halinde kumar ve buna benzer oyunlar oynadıkları bildirildi. Bunun sonucunda Ferid Paşa'nın sürülmesine, diğerlerinin de memuriyetlerinde değişiklik yapılmasına karar verildi (BOA, DH. ŞFR., 542/77: 1, 1-2, 8 Ocak 1917).

Memurların kumar alışkanlıklarıyla ilgili örnekleri çoğaltmak mümkündür. $\mathrm{Bu}$ konuda şikayetlerin Sadrazamlık makamına ulaşması üzerine Sadrazam Talat Paşa, ivedilikle harekete geçti ve gerekli incelemelerin başlatılmasını istedi. Örneğin Talat Paşa imzasıyla Niğde Mutasarrıflığına gönderilen telgrafta, Muhacirin Sevk Memuru Cemal Efendi'nin kumar oynadığı, muhacirlerin yevmiyelerinden alarak görevini kötüye kullandığı, bu nedenle memurun işine son verilerek hakkında gerekli kanuni işlemin başlatılması ve tahkikat sonucunun bildirilmesi istendi (BOA, DH.ŞFR., 74/302: 1-1, 29 Mart 1917).

Diğer bir örnek olarak Halep Vilayeti polis müdürü hakkında yapılan bir şikayet üzerine Talat Paşa tarafından Halep Vilayeti'ne çekilen telgrafta, Halep Polis Müdürü Saadettin Bey'in kumara başladığıyla ilgili haber alındığı, hakikatin araştırılarak bir an evvel nezarete bildirilmesi istendi (BOA, DH.ŞFR., 76/89: 1-1, 15 Mayıs 1917). Halep Vali Vekili Mehmed Tevfik Bey tarafından Dahiliye Nezareti'ne gönderilen cevabi yazıda Halep Polis Müdürü Saadettin Bey'in kumara başladığına dair bir malumat elde edilemediği bildirildi (BOA, DH. ŞFR., 554/29: 1-1, 15 Mayıs 1917).

Kumar oynayan memurlar yanında kumar oynanmasına müsaade eden memurlar hakkında da yasal işlem yapıldığı anlaşılmaktadır. Özellikle kolluk memurları kumar oynanmasına müsaade etmeleri halinde cezalandırılmışlardır. Bununla ilgili çok sayıda belge bulunmaktadır. 29 Ağustos 1918 tarihli olup Ankara Vilayeti polis memurlarından Niyazi Bey'in durumunu anlatan bir belge buna örnek gösterilebilir. Belgede yer alan bilgiye göre Niyazi Bey, kumar oyununa müsaade ettiği ve rüşvet aldığı gerekçesiyle mahkeme edilmiş ve suçlu bulunmuştur. Ancak polis memuru karara itiraz etmiştir. Bunun üzerine Dahiliye Nezareti tezkere ile durumu Şura-yı Devlet'e havale etmiştir. Şura-yı Devlet yaptığı inceleme sonucunda memurun rüşvet aldığına dair bir kanıt bulamamış, ancak vazifesinin gereği olarak, kumar oynanmasına müsaade etmemesi gerekirken buna göz yumduğunun anlaşılması üzerine aldığı cezayı tasdik etmiştir (BOA, ŞD., 1323/18: 1, 3, 5, 29 Ağustos 1918).

Alınan yasal önlemler ve polisiye tedbirlere rağmen kumar alışkanlığı tümüyle ortadan kaldırılamadı. Ancak Dahiliye Nezareti kumarla ilgili çeşitli tarihlerde uyarılar göndermeye devam etti. Söz konusu uyarılarda Ceza Kanununun 242. maddesi gereğince kumar oynatılmasının yasak olduğu hatırlatılarak bu hükümlerin istisnasız tatbik edilmesi istendi (BOA, DH.UMVM., 124/180: 1-1, Eylül 1918). 


\section{SONUÇ}

I. Dünya Savaşı ve sonrasında yaşanan gelişmeler Osmanlı Devleti için birçok alanda derin sarsıntıların yaşandığı bir süreçtir. Savaşın getirdiği ekonomik ve siyasi buhranlar toplumsal hayatı da derinden etkiledi. Olağan zamanlarda yapılması sakıncalı görülen, dinî ve hukukî olarak yasaklanmış olan sefahat, içki, kumar, eğlence ve fuhuş gibi alışkanlıklar aleni hale geldi. Özellikle 1917 Rus İhtilali sonrasında İstanbul'a çok sayıda Rus göçmenin gelmesiyle birlikte eğlence hayatı çeşitlendi ve buna bağlı olarak umumhaneler çoğaldı, fuhuş ve kumar gibi alışkanlıklar ise yaygınlaştı.

Osmanlı arşiv kaynaklarından izlendiği kadarıyla İttihat ve Terakki Hükümeti ve devlet ricali kumara karşı kınayıcı ve engelleyici bir yaklaşım içinde oldu. Bunun yanında devlet, suç sayılan kumara karşı ahlakî ve dinî bakımdan kınamanın yasal bir uzantısı olarak cezalandırmak amacıyla gerekli hukukî düzenlemeleri yaptı. Özellikle Talat Paşa'nın halk arasında kumarın yaygınlaşmasını engellemek için kahvehaneleri sıkı bir denetim altında tutma çabası önemlidir. Bu meyanda kumar oynandığı tespit edilen kahvehanelere polis tarafından baskınlar yapıldı. Ancak bu baskınlar kahvehane işletenlerin geliştirdikleri teknikler sayesinde önceden haber alınınca akamete uğradı.

I. Dünya Savaşı sürecinde kumar illeti devlet memurları arasında da yaygınlık kazanmış idi. Devlet memurlarının kumar oynamalarına ilişkin şikâyetlerin artması üzerine devlet her düzeyde devlet memurunun kumar alışkanlıklarını ortadan kaldırmak ya da engellemek için hukukî ve inzibatî tedbirler aldı. Dahiliye Nazırı Talat Paşa'nın bu konudaki çabası dikkate değerdir. Memurların kumar oynamasını engellemek için bir nizamname oluşturulması onun çalışmaları sonucunda oldu. Nitekim 5 Aralık 1917'de Meclis-i Vükela kararına göre devlet memurlarının kumar oynamaları yasaklandı. Yasağı ihlal edenlere birinci defasında uyarı, ikinci defasında tam maaş kesimi ve üçüncü defasında ise memuriyetten azl edilme cezası getirildi.

Kumarı yok etmek için alınan hukukî tedbirler köklü bir çözüm getiremedi. Çünkü kumarın yaygınlaşmasına sebep olan olumsuz sosyal ve ekonomik şartları yok etmek mümkün olmadı. Mütareke döneminin müphem koşulları, asayişsizlik, İtilaf komiserlerinin keyfi tutumları kumarın aleni hale gelmesinde etkili oldu. Bu nedenle kumar meselesi Cumhuriyet döneminin de en önemli toplumsal sorunları arasında yerini aldı ve çeşitli yasalarla engellenmeye çalışıldı.

\section{SUMMARY}

The purpose of the study was identified as to investigate the proliferation of gambling as an indicator of social disintegration during and after the World War I and the precautions for this problem taken by the Ottoman State.

In the studies related to social problems of the Ottoman State during the years of the World War I, gambling was not examined in itself. These studies were addressed in the scope of the issues such as proliferation of prostitution, nightlife, and epidemic illnesses during the Armistice period. In other words, gambling is an issue that was discussed briefly as a part of reviewing the indicators of social disintegration but was not investigated in detail. This study was conducted in order to fill the gap in the field. Within this framework, the study elaborated on the precautions taken by the Ottoman Government in parallel with proliferation of gambling that disturbed the social order and security of the country. Thus, the study revealed the precautions taken by the state during the period that social change SEFAD, 2019; (41): 405-426 
and disintegration occurred to a high degree in order to protect social ethics, the ways in which they were carried out, and how it was seen in the society.

For the purpose of achieving the goals of study, in the first step, the researcher investigated the data gathered from the Ottoman Archives of the Presidency, the Republic Archives of the Presidency, ATASE Archive of General Staff, Kızılay Archive, the Library of the Grand National Assembly of Turkey, National Library, and the Libraries of Turkish Historical Society. Archive documents dealing with the social effects that the World War I caused in the Ottoman society and gambling were identified and obtained. Moreover, articles about gambling in the press were also examined attentively by scanning the laws and regulations introduced about gambling during the World War I, and the Ottoman periodicals. Furthermore, academic publications related to the issue were also found. In this context, gambling in the Ottoman State during the years of the World War I and the precautions taken by the state in order to prevent gambling were addressed in a historical point of view by considering the archive sources and historical data obtained. Also, answers were looked for the research questions and hypotheses.

In order to conduct the scientific study in the targeted way, the following issues were investigated and discussed: how did gambling habit as an indicator of social disintegration affect the social life? What were the precautions taken by the Ottoman State in order to prevent gambling? What were the attitudes of public officers and soldiers in the Ottoman State about gambling and/or making gambling possible? What were the sanctions related to gambling habits in the Ottoman State and especially for public officers? How were the legal, political, and social precautions basically taken by the state for preventing gambling seen in the society? Or were they enough to prevent gambling?

In the study, it was emphasised that the social disintegration with war occurs quickly and traumatically in the societies in which social change accelerates. Moreover, some observations were made and some analyses were carried out in order to analyse the effect of gambling on social disintegration according to the information in the sources.

The research has shown that the social and economic effects of the World War I caused some changes in traditional habits. A number of problems appearing during war periods such as economic troubles, poverty, unemployment, famine, lack of inspection, and prostitution led to social disintegration, and the behaviours that were accepted to be inconvenient at ordinary times might become common during war periods. In conjunction with all these problems, there was a serious increase also in gambling and chance games during war periods. Moreover, the fact that soldiers at different geographies due to war carried gambling habits of their own lands to the places out of their countries made gambling become common. Some gambling games played nationally became international. Hence, it appeared that the reasons of the increase in gambling in the Ottoman geography were nightlife that was enlivened and gambling and prostitution that were proliferated in İstanbul after the arrival of the Russian soldiers in İstanbul.

The elimination of these habits that had long-continued effects, debilitated the social ethics, and disturbed the peace and public order necessitated the state to fight against this matter for a long period. Likewise, the interest also appeared for prostitution, alcohol consumption, and excessive entertainment in social environments which involved gambling. In this respect, the prohibition of gambling was one of the most important social duties of 
the state in order to ensure public order and safety. Especially, gambling at the coffeehouses and places of entertainment damaged family structure and led to economic problems. In order to be able to eliminate the proliferation of gambling and chance games, the state took various precautions. It can be easily said that the executives of the Ottoman State evaluated the gambling and chance games proliferating more and more in the society as a social problem. For this purpose, as far as it could be followed from the archive documents, regulations for preventing gambling and other chance games were consistently made. In this regard, articles regarding this issue were put in penal codes, and deterrent precautions were taken by preparing regulations especially about gambling proliferation among public officers. Gambling habits of the public officers put the security of the state into trouble during the war period. For this reason, even the punishment of disqualification from official duty was implemented in order to keep public officers away from gambling and to prevent them from being open to bribery due to gambling.

The legal precautions taken for eliminating gambling could not deliver a radical solution because it was not possible to eliminate the negative social and economic conditions that caused gambling to become widespread. Indefinite conditions of the armistice period, insecurity, and arbitrary behaviours of the allied commissioners were effective in that gambling became common. Consequently, the gambling problem was also among the most important social problems of the Republic period, and it was attempted to be prevented through various laws. 


\section{KAYNAKÇA}

\section{Osmanlı Arşivi (BOA) Belgeleri}

Bâb-1 Âlî Evrak Odası (BEO), 2326/174390, (15 Nisan 1320/28 Nisan 1904); 4495/337056, (5 Kanunuevvel 1333/5 Aralık 1917); 4495/337056, (8 Teşrinisani 1333/8 Kasım 1917).

Dahiliye Emniyet-i Umumiye Asayiş Kalemi Evrakı (DH.EUM.AYŞ.), 2/30, (29 Mart 1335/1919); 66/24, (11 Haziran 1335/1919); 13/52, (24 Haziran 1335/1919).

Dahiliye Emniyet-i Umumiye Memurin Kalemi Evrakı (DH.EUM.MEM.), 60/90, (29 Rebiülevvel 1333/14 Şubat 1915).

Dahiliye Emniyet-i Umumiye Tahrirat Kalemi Evrak1 (DH.EUM.THR.), 64/82, (Cemaziyelevvel 1329/Nisan-Mayıs 1911).

Dahiliye Emniyet-i Umumiye Takibat-1 Adliye Kalemi Evrakı (DH.EUM.ADL.), 48/19, (15 Eylül 1333/1917).

Dahiliye Nezareti Emniyet-i Umum Müdüriyeti 2. Şube Belgeleri (DH.EUM. 2. Şube), 26/9, (14 Temmuz 1332/27 Temmuz 1916, 27 Temmuz 1332/9 Ağustos 1916); 39/24, (2 Temmuz 1333/1917).

Dahiliye Nezareti Emniyet-i Umum Müdüriyeti 5. Şube Belgeleri (DH.EUM. 5. Şube), 20/19, (19 Kanunuevvel 1331/1 Ocak 1916).

Dahiliye Nezareti Emniyet-i Umumiye Kism-1 Adli Kalemi (DH.EUM.KADL.), 2/52, (12 Kanunuevvel 1326/25 Aralık 1910).

Dahiliye Nezareti İdare Evrakı (DH.ID.), 891/2, (15 Ağustos 1326/28 Ağustos 1910).

Dahiliye Nezareti İdare-i Umumiye Evrakı (DH.İ.UM.), 19-7/1-34, (Ramazan 1337/ MayısHaziran 1919); 19-7/1-34, (21 Ağustos 1335/1919); 19-7/1-34:, (12 Haziran 1335/1919); 1921/1-68, (20 Eylül 1337/1921); 19-21/1-68, (Eylül 1921); 19-21/1-68, (31 Eylül 1337/1921).

Dâhiliye Nezareti İdare-i Umumiye Kalemi Ekleri (DH.İ.UM.EK.), 44/57, (13 Kanunuevvel 1333/13 Aralık 1917).

Dahiliye Nezareti Mebani-i Emiriye-Hapishaneler Müdüriyeti Evrakı (DH.MB.HPS.), 77/6, (14 Mart 1333/1917); 77/6, (13 Mayıs 1333/1917); 90/61, (26 Haziran-16 Ağustos 1330/9 Temmuz-29 Ağustos 1914); 99/8, (29 Eylül 1336/1920); 99/8, (30 Eylül 1336/1920).

Dahiliye Nezareti Mebani-i Emiriye-Hapishaneler Müdüriyeti Müteferrik Evrakı (DH.MB.HPS.M.), 33/31, (15 Nisan 1334/1918).

Dahiliye Nezareti Mektubî Kalemi (DH.MKT.); 1778/69, (22 Rebiülevvel 1308/5 Kasım 1890); 851/73, (27 Nisan 1320/10 Mayıs 1904); 908/37, (7 Kasım 1904); 908/37, (26 Teşrinievvel 1320/8 Kasım 1904); 908/83, s. 1-1, 2-2, (9 Kasım 1904).

Dahiliye Nezareti Şifre Kalemi Belgeleri (DH.ŞFR.), 66/192, (27 Temmuz 1332/9 Ağustos 1916); 66/56, (9 Temmuz 1332/22 Temmuz 1916); 74/302, (29 Mart 1333/29 Mart 1917); 76/89, (15 May1s 1333/1917); 87/217, (20 May1s 1334/1918); 542/77, (26 Kanunuevvel 1332/8 Ocak 1917); 554/29, (15 May1s 1333/1917).

Dahiliye Nezareti Umur-1 Mahalliye ve Vilayat Müdürlüğü Evrakı (DH.UMVM.), 124/130, (9 Kanunusani 1334/9 Ocak 1918); 124/180, (Eylül 1334/1918).

Divan-1 Hümâyûn Defterleri Kataloğu Mühimme Defterleri (A.DVNS.MHM.d), (Dosya/Gömlek) 35/225, (Cemaziyelevvel 986/Temmuz-Ağustos 1578).

Hariciye Nezareti Sofya Sefareti (HR.SFR.04), 650/51, (23 Mart 1916); 651/67, (13 Nisan 1916); 651/83, (2 Nisan 1916); 651/83, (11 Nisan 1916); 651/83, (14 Nisan 1916); 651/83, (3 May1s 1916); 888/17, (Nisan 1916); 902/17, (2 Nisan 1916); HR.SFR.04, 902/17, (14 Nisan 1916); 902/64, (14 Nisan 1916); 902/69, (14 Nisan 1916); 903/27, (3 Mayıs 1916).

Maarif Nezareti Mektubi Kalemi (MF.MKT.), 1232/29, (25 Kanunuevvel 1333/25 Aralık 1917); 1232/37, (25 Kanunevvel 1333/25 Aralık 1917). 
Meclis-i Vükela Mazbataları (MV.), 210/78, (5 Kanunuevvel 1333/5 Aralık 1917); 221/102, (6 Nisan 1337/1921); 224/59, (15 Ağustos 1338/1922).

Şura-yı Devlet Evrakı (ŞD.), 2364/01, (23 Şubat 1319/7 Mart 1904); 657/58, (10 Teşrinievvel 1329/23 Ekim 1913); 1323/18, (29 Ağustos 1334/29 Ağustos 1918); 2838/30, (23 Ağustos 1332/5 Eylül 1916); 2838/30, (2 Ağustos 1332/15 Ağustos 1916); 2838/30, (3 Ağustos 1332/16 Ağustos 1916); 2838/30, (20 Eylül 1332/3 Ekim 1916); 2838/30, (16 Teşrinievvel 1332/29 Ekim 1916); 2838/30, (4 Teşrinisani 1332/17 Kasım 1916); 2838/30, 4 Teşrinisani 1333/4 Kasım 1917; 2839/12, (11 Kanunuevvel 1333/11 Aralık 1917).

Yıldız Perakende Evrakı Mâbeyn Başkitâbeti (Y.PRK.BŞK.), 68/80, (29 Zilhicce 1320/29 Mart 1903).

\section{Diğer Kaynaklar}

“Ceza kanunname-i hûmayunu" (1289). 28 Zilhicce 1274/9 Ağustos 1858, Düstur. Tertip I/I. Matbaa-yı Amire.

“Musahabe kumar meselesi” (1333.Kanunuevvel.27). Servet-i Fûnun. C. 53, No: 1373, (27 Aralık 1917), 342.

"Polis nizamnamesi" (1335). Düstur, Tertip I. Mütemmim. (15 Muharrem 1269-8 Recep 1325) Dersaadet: Hilal Matbaası.

"Sirkatler "hırsız kumarbazlar"”" (1336.Teşrinievvel.1). Polis Mecmuası. Aded: 78, Dördüncü Sene, 339-342.

Ahmed L. (1304). Mir'at-ı adalet yahud tarihçe-i adliye-i Devlet-i Aliye. Naşiri: Kitapcı Ohannes, İstanbul: Matbaa-i Nişan Berberyan.

Akgündüz, A. (1986). Mukayeseli İslam ve Osmanl hukuku külliyatı. Diyarbakır: Dicle Üniversitesi Hukuk Fakültesi Yayınları

Akgündüz, S. N. (2016). Tanzimat dönemi Osmanlı ceza hukukunun kaynakları. Dergiabant (Abant İzzet Baysal Üniversitesi İlahiyat Fakültesi Dergisi), IV(8), 1-16.

Aydın, M. A. (1993). Osmanlı ceza hukuku. İslam Ansiklopedisi. C. VII. (s. 481-482). İstanbul: Türkiye Diyanet Vakfı Yayınları

Bardakoğlu, A. (2002). Kumar. İslam Ansiklopedisi. C. XXVI. (p. 364-367). İstanbul: Türkiye Diyanet Vakfı Yayınları

Dikici, A. (2014). II. Meşrutiyet'ten Cumhuriyet'e miras kalan iç güvenlik anlayışı ve polis teşkilatı. Türk İdare Dergisi, 479, 91-122.

Necmeddin Sadık(1918.08.15). "Hafta musahabesi kumar". Yeni Mecmua, C. III, S.57, 1.

Öner, S. (2013). Çeviri yoluyla kanun yapmak: 1858 tarihli Osmanl ceza kanunu'nun 1810 tarihli Fransız ceza kanunu'ndan çevrilmesi (Doktora Tezi). İstanbul, Yıldız Teknik Üniversitesi.

Şentop, M. (2005). Tanzimat dönemi kanunlaştırma faaliyetleri literatürü. Türkiye Araştırmaları Literatür Dergisi, III(5), 647-672.

Temel, M. (1998). İsgal yıllarında İstanbul'un sosyal durumu. Ankara: Kültür Bakanlığ1 Yayınları

Toprak, Z. (1987). İstanbul'da fuhuş ve zührevi hastalıklar 1914-1933. Tarih ve Toplum, 39, 3140.

Toprak, Z. (2012). Türkiye'de milli iktisat 1908-1918. İstanbul: Doğan Kitap.

Toprak, Z. (2017). Türkiye'de yeni hayat inkılap ve travma 1908-1928. İstanbul: Doğan Kitap.

Yakut, K. ve Aydın Y. (2011). “II. Meşrutiyet dönemi'nde toplumsal ahlak bunalımı: fuhuş meselesi". Kebikeç 31: 275-307.

Yolal, M. (2018). Osmanl Devleti'nde şans oyunlar ve kumar (1800-1923). (Doktora Tezi). Gaziantep, Gaziantep Üniversitesi.

SEFAD, 2019; (41): 405-426 


\section{EKLER:}

Ek-1 Halep'te Baron Oteli Sahibi Baron'un Otelini Kumar ve Fuhuş Yuvasına Dönüştürdüğü ve Devlet Memurlarını Kullandığına Dair Belge

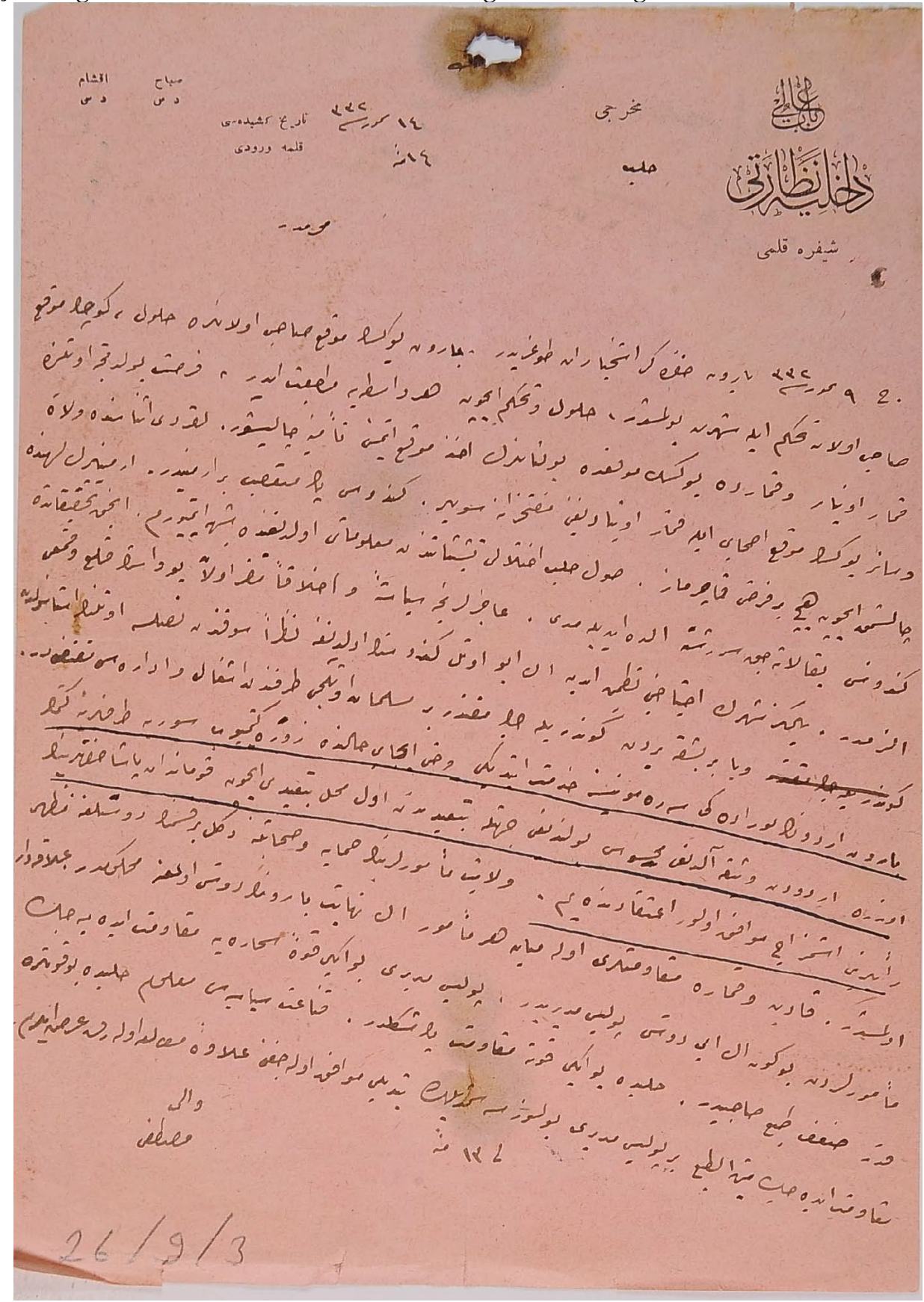

BOA, DH.EUM. 2. Şube, 26/9 (14 Temmuz 1332/27 Temmuz 1916). 